\title{
LITURGIA, PROTOKÓł, CEREMONIAł, ETYKIETA. KU SYSTEMATYZACJI POJĘĆ I OKREŚLENIU WZAJEMNYCH RELACJI
}

DOI: http://dx.doi.org/10.12775/TiCz.2021.031

„... aby język giętki, powiedział wszystko, co pomyśli głowa...”.

J. Słowacki

Streszczenie. Zarówno analizy kształtowania się i systematyzowania liturgicznych gestów, postaw, znaków i symboli podejmowane w historii, jak i badania nad proweniencją dzisiejszej etykiety oraz zasad ceremonialnych i protokolarnych stosowanych w działaniach dyplomatycznych ukazują szereg zależności pomiędzy tymi dwiema, jakby się mogło wydawać, odległymi płaszczyznami, jakimi są liturgia i dyplomacja. W opracowaniu przedstawiono relacje zachodzące pomiędzy dyplomacją jako najstarszą instytucją w stosunkach między państwami (wyrażaną poprzez ceremoniał, protokół i etykietę) i liturgią Kościoła. Ze względu na trudności związane z niejednoznacznością tych terminów, w artykule podjęto także próbę usystematyzowania odnośnej terminologii.

Słowa kluczowe: liturgia, dyplomacja, protokół, ceremonia, etykieta.

Abstract. Liturgy, Protocol, Ceremonial, Etiquette: Towards the Systematization of Terms and Definition of the Mutual Relationship. Analyses of the development and systematization of liturgical gestures, postures, signs and symbols undertaken in his- 
tory and studies on the provenance of today's etiquette and principles of ceremony and protocol used in diplomacy both reveal a number of interrelationships between the two seemingly distant fields of liturgy and diplomacy. This article presents the relationship that exists between diplomacy as the oldest institution in relations between states (expressed by ceremonial, protocol and etiquette) and the liturgy of the Church. Due to the difficulties resulting from the ambiguity of the terms, the article also attempts to systematize the relevant terminology.

Keywords: liturgy, diplomacy, protocol, ceremonial, etiquette.

\section{WSTĘP}

Greckie „diploma”, od którego wywodzi się termin „dyplomacja”, znaczy tyle co „podwójny”. Przeważające, choć nie do końca pewne opinie wskazują, że jest to nawiązanie do urzędowych aktów, w formie dwóch glinianych tabliczek, wydawanych posłom w starożytnej Grecji i zapewniającym im szczególne przywileje. Natomiast w starożytnym Rzymie był to dokument stanowiący rodzaj paszportu, czy też rekomendację ${ }^{1}$. W niniejszym opracowaniu pragniemy przedstawić relacje pomiędzy dyplomacją jako najstarszą instytucją w stosunkach między państwami (wyrażaną poprzez ceremoniał, protokół i etykietę) i liturgią Kościoła. Napotykamy jednak na pewne trudności związane z niejednoznacznością tych terminów, dlatego w naszej refleksji postaramy się również usystematyzować odnośną terminologię.

Zarówno analizy kształtowania się i systematyzowania liturgicznych gestów, postaw, znaków i symboli podejmowane w historii, jak i badania nad proweniencją dzisiejszej etykiety oraz zasad ceremonialnych i protokolarnych stosowanych w działaniach dyplomatycznych ukazują szereg zależności zachodzących pomiędzy tymi dwiema, jakby się mogło wydawać, odległymi płaszczyznami, jakimi są liturgia i dyplomacja. Tymczasem rzeczywistości te ściśle ze sobą współbrzmią (także w sensie rozumienia związanych z nimi pojęć), a nawet wzajemnie uzupełniają i przenikają. Rzecz jasna, że liturgia - jako rzeczywistość Bosko-ludz-

1 Zob. J. Sutor, Prawo dyplomatyczne i konsularne, Warszawa 2021, s. 23; S. Nahlik, Narodziny nowożytnej dyplomacji, Wrocław 1971, s. 1-2; R. Genet, Traité de Diplomatie et de Droit Diplomatique, Paris 1931, t. 1, s. 11-12. 
ka - w swym wymiarze nadprzyrodzonym pozostaje zupełnie na innej płaszczyźnie ontycznej. Stąd nasza refleksja dotyczy ludzkiego, by nie rzec ceremonialnego (a jeśli czasem także Boskiego, to postrzegalnego zmysłami) aspektu liturgii ${ }^{2}$.

Liturgia chrześcijańska, w tym przede wszystkim jej wymiar kultyczny, od samego początku czerpie z zasad i reguł panujących w relacjach międzyludzkich (indywidualnych i zbiorowych), jednocześnie nie pozostając bez znaczenia dla kształtującego się porządku spotkań oraz stylu prowadzenia rozmów. Zarówno liturgia Kościoła, jak i zasady protokolarne posiadają wspólne korzenie, jakimi są elementy starożytnych kultów. Są one swoistym prototypem zewnętrznych form liturgii chrześcijańskiej, jak i reguł protokołu dyplomatycznego ${ }^{3}$. Podobnie, zasady tworzone na rzymskim dworze cesarskim nie były jedynie częścią jakiegoś porządku obowiązującego w relacjach międzyludzkich, czy szerzej międzynarodowych, ale również odnajdywały swoje odzwierciedlenie w czynnościach liturgicznych. Działo się tak zwłaszcza od IV wieku naszej ery chrześcijańskiej, po Edykcie Mediolańskim, kiedy to do klasycznej liturgii rzymskiej zaczęło przenikać coraz więcej elementów ceremoniału dworskiego ${ }^{4}$.

\section{PROTOKÓł LITURGIĄ DYPLOMACJI}

W opracowaniu dotyczącym działalności placówek dyplomatycznych i pracy dyplomaty, T. Orłowski przyrównuje protokół dyplomatyczny (a więc zespół zasad i reguł, gestów, czynności i postaw, będących wyrazem podejmowanych działań i nawiązywanych relacji) do liturgii.

Protokół - stwierdza T. Orłowski - uchodzi za liturgię i gramatykę dyplomacji. Kryjąca się poza nim treść musi być dostatecznie ważna, a przekonanie o jej doniosłości dostatecznie silne, w przeciwnym bowiem razie zewnętrzne przejawy protokołu musiałyby się wydać niezrozumiałym

2 Zob. D. Brzeziński, Human Dimension of the Christian Liturgy, „Teologia i Człowiek" 48 (2019), s. 71-89.

3 Zależności zachodzące między światem antycznym a chrześcijańską liturgią przedstawił J. Janicki, Kultury antyczne w liturgii chrześcijańskiej, Kraków 2007.

${ }^{4}$ Por. D. Brzeziński, W poszukiwaniu teologicznego sensu liturgii. Refleksje na 2000-lecie chrześcijaństwa, „Studia Płockie” 28 (2000), s. 38-39. 
fetyszem lub niedorzecznością. Jako liturgia dyplomacji stanowi rytualną oprawę jej działań i tworzy jej obrzędowość, jako gramatyka dyplomacji kodyfikuje zasady budowy jej języka, słów, gestów i zachowań ${ }^{5}$.

Spostrzeżenie polskiego dyplomaty jest ciekawe nie tylko z powodu zaskakującego przyrównania dyplomacji do liturgii, rzeczywistości - wydawać by się mogło - odległych i niezależnych od siebie, ale również dlatego, iż ukazuje użycie w praktyce terminu, dziś sensu stricto łączonego niemal wyłącznie z działalnością i misją Kościoła, w zupełnie innym kontekście, a może i w innym znaczeniu. Tymczasem, wspomniana „rytualna oprawa działań” dyplomacji bardzo często w języku roboczym pracowników misji dyplomatycznej nazywana jest właśnie liturgią.

Etymologicznie termin „liturgia”, wywodzący się od dwóch słów z języka greckiego w dialekcie attyckim: „laos” (ludowy) i „ergon” (czyn, działanie), dosłownie oznacza czyn ludowy, publiczny, społeczny. Świadomość proweniencji tego terminu, a także jego historycznych zaszłości ukazuje, że używanie go jest uzasadnione zarówno na płaszczyźnie politycznej, kulturowej, społecznej, jak i religijnej.

Wertując karty Pisma Świętego oraz dzieła starożytnych myślicieli i pisarzy, zauważamy, że słowo „liturgia” używane jest w różnych kontekstach i odnoszone jest do różnych czynności i różnorakiej działalności. W starożytnej Grecji liturgią określano między innymi organizację igrzysk, biegów, utrzymanie chóru, organizację festiwali, a także przygotowanie poselstwa oraz okrętów wojennych ${ }^{6}$. W korpusie greckiej literatury słowo to występuje 403 razy, w 94 dziełach. Używają go zarówno mówcy, politycy, historycy, jak i kapłani; tak poganie, jak i chrześcijanie. Termin „leiturgia” odnajdziemy u Arystotelesa (16 razy), Demostenesa (47 razy), Józefa Flawiusza (13 razy), a także u św. Bazylego Wielkiego (8 razy), Euzebiusza z Cezarei (30 razy), Juliana Apostaty (9 razy) czy św. Jana Damasceńskiego (1 raz). Tworzący w języku greckim starożytni pisarze używają wyrażenia w pierwszej kolejności w odniesieniu do polityki, a następnie

5 T. Orłowski, Protokół dyplomatyczny. Między tradycją a nowoczesnością, Warszawa 2015, s. 21.

6 Zob. B. Nadolski, Liturgika, t. 1: Liturgika fundamentalna, Poznań 1989, s. 9-10. 
do życia społecznego, określając nim działania służące innym, czyny wykonywane dla innych, na korzyść innych ${ }^{7}$.

W języku greckim biblijnym słowo „liturgia” pojawia się 47 razy (a licząc pochodne tego słowa, 173 razy). Septuaginta rozumie je przede wszystkim jako kultyczną służbę, ryty wykonywane w świątyni, publiczny kult. Nowy Testament słowa „liturgia” używa zaledwie 15 razy: w znaczeniu kultu Starego Testamentu, służby publicznej (jak pobieranie podatków czy zbiórka darów na rzecz potrzebujących), a także nowotestamentalnego kultu duchowego, który nie wyklucza form publicznych i obrzędowych ${ }^{8}$.

Powszechny w starożytności - zarówno w znaczeniu świeckim, jak i religijnym - grecki termin „liturgia” dość szybko został zapomniany i praktycznie nie był używany w Kościele zachodnim aż do czasów renesansu, pomimo przyjęcia i zadomowienia się w Kościele łacińskim - w zlatynizowanej pisowni i brzmieniu - szeregu innych greckich terminów religijnych. W łacińskiej formie „wprowadził” go w epoce nowożytnej G. Cassander w 1558 roku, głównie w badaniach dotyczących starożytnych ksiąg liturgicznych. W odniesieniu do kultu Kościoła słowa „liturgia” użył kardynał J. Bona w roku 1671, a także J. Mabillon - w 1685 roku - na określenie formularzy sprawowania po łacinie Mszy świętej ${ }^{9}$. Należy zauważyć, że słowo to używane jest we współczesnej grece do dziś. Oznacza pracę (silnika, serca), można je również spotkać na wywieszkach greckich urzędów jako określenie godzin przyjęć interesantów.

Współcześni badacze liturgii podkreślają, że liturgia - w świetle teologii liturgii - jest przede wszystkim anamnezą Misterium Paschalnego Pana Jezusa, celebrowaną hic et nunc przez wspólnotę Kościoła, a więc Chrystusa-Głowę i członki Jego Mistycznego Ciała, i wyrażaną poprzez sprawowanie świętych czynności zgodnie $\mathrm{z}$ wielowiekową tradycją i zwyczajem $^{10}$.

7 Zob. Leiturgia, w: Liddell-Scott-Jones.

8 Zob. B. Nadolski, Liturgika..., s. 9-10.

9 Zob. S. Marsili, La liturgia, momento storico della salvezza, w: tenże (red.), Anàmnesis, t. 1: La liturgia, momento nella storia dela salvezza, Casale Monferrato 1979, s. 33-45; tenże, Liturgia, w: D. Sartorte, A. M. Triacca (red.), Nuovo Dizionario di Liturgia, Cinisello Balsamo 1990, s. 726-727.

10 Zob. D. Brzeziński, „Chrystus wczoraj i dziś, i na wieki”. Anamnetyczny wymiar roku liturgicznego, Toruń 2015. 
Podobnie liturgia dyplomacji, a więc protokół, nie jest tylko zbiorem gestów i czynności, zbiorem przestarzałych zasad i dawnych zwyczajów, ale wyrazem ducha przejawiającym się w kulturze spotkania, wyrazem relacji zachodzących pomiędzy uczestnikami dyplomatycznego wydarzenia. Cytowany już T. Orłowski, wspominając o twórcy i pierwszym szefie Protokołu Dyplomatycznego polskiego Ministerstwa Spraw Zagranicznych Stefanie Przeździeckiem, przywołał opinię, która doskonale oddaje rzeczywistość dyplomatycznego spotkania - liturgii oraz roli dyplomaty - liturga ${ }^{11}$.

„Jego [Stefana Przeździeckiego] wysoka kultura - pisał T. Orłowski - takt, życzliwość były też wzorem dla domorosłych dyplomatów niższego szczebla, którym za atrybut przynależności do stanu dyplomatycznego zdawały się wystarczać dobrze skrojone żakiety, sztuczkowe spodnie i znaczna ilość brylantyny”. Protokół nie może bowiem nigdy być pustą formą ${ }^{12}$.

\section{WSZYSTKO JEST CEREMONIĄ}

Abraham de Wicquefort, holenderski dyplomata, rezydent polskiego króla w Niderlandach, w dziele zatytułowanym Memoires touchant les ambassadeurs, et les ministres publics, zanotował: „Où tout est cérémonie” (Wszystko jest ceremonią) ${ }^{13}$. Kształtujący się od zarania dziejów ceremoniał przenikał każdą sferę życia, zarówno tę religijną, jak i społeczną oraz polityczną. Problematyka ceremonii, a także jej układu, czyli ceremoniału, ściśle wiąże się z protokołem, tzn. obowiązującym porządkiem. Wskazane terminy używane są zarówno przez liturgistów ( $\mathrm{z}$ wyjątkiem słowa „protokół”, które zastępuje „porządek”), jak i dyplomatów; i odnoszą się do dwóch rzeczywistości, dziś różnych i coraz bardziej odległych, niegdyś spójnych i ściśle od siebie zależnych.

${ }^{11}$ Liturg, w nawiązaniu do kultury antycznej, to osoba organizująca lub wypełniająca czyn publiczny, czyli liturgię. W historii i teologii liturgii „Liturg” to Jezus Chrystus, Najwyższy i Wieczny Kapłan, który sprawuje wieczną liturgię, ale „liturgami” są także ludzie sprawujący liturgię Kościoła.

12 T. Orłowski, Protokół dyplomatyczny..., s. 17.

13 A. de Wicquefort, Memoires touchant les ambassadeurs, et les ministres publics, La Haye 1677, s. 229. 
W opracowaniach poświęconych historii dyplomacji niejednokrotnie podkreślany jest fakt, że towarzyszący zarówno w życiu codziennym, jak i podczas szczególnych wydarzeń porządek (łac. ordo - porządek, gr. protokolon - pierwsza część zwoju, spis zawartości, pierwsza wersja dokumentu, wzór ${ }^{14}$ ) kształtował się w sposób naturalny, od samego początku, kiedy tylko pojawił się człowiek i zaczął nawiązywać relacje z otaczającym go światem. Przyjmując coraz to bardziej rozbudowane formy, cały czas opierał się na podstawowych potrzebach i zasadach, które towarzyszyły człowiekowi „od zawsze” (np. szacunek dla starszych, zajmowanie miejsca przy stole, gościnność, rozwiązywanie problemów itp. ${ }^{15}$.

Samuel B. Linde w przygotowanym przez siebie pierwszym jednojęzycznym słowniku języka polskiego zamieszcza podział na ceremonie rozumiane jako uroczyste obrzędy religijne oraz ceremonie „w rzeczach cywilnych” (tj. świeckich), rozumiane jako oznaki poszanowania, dochowanie zwyczaju i tradycji. Podkreśla również trzecią płaszczyznę użycia tego terminu - „życie potoczne” (codzienne): pozory, komplementy, konwenanse (ceregiele), przywołując jednocześnie różnego rodzaju powiedzenia, jak np. „nie rób ceremonii”, „bez ceregieli” itp. ${ }^{16}$

Złożoność terminu „ceremonia”, jak i jemu pokrewnych („ceremoniał”, „ceremonialny”, „ceremoniarz”) wymaga przytoczenia przykładów jego użycia, co pozwoli na pełniejsze jego zrozumienie; zrozumienie bardziej kompleksowe, niż tylko to wynikające z definicji słownikowych. Kolejny badacz A.J. Nowowiejski w poszukiwaniu etymologii tego wyrażenia przytacza kilka możliwości. Zwróćmy uwagę na trzy najbardziej prawdopodobne: od łac. Cereris munia (tj. ofiar składanych bogini zboża Cererze); od łac. caerus (który znaczy to samo co sanctus); od miasta Caeres w Etrurii, niedaleko Rzymu. Nowowiejski tak pisał:

[Do Etrurii] po zdobyciu Rzymu przez Galów, schroniły się, unoszące z sobą święty ogień i posągi bogów, westalki, gdzie, że przyjęte były życzliwie, dla pamięci wdzięcznej tego Rzymianie mieli postanowić, aby każdy

14 Zob. Protokolon, w: Słownik Liddell-Scott-Jones; oraz hasło Protocollum w: Dictionary of Medieval Latin from British Sources.

15 Zob. J. Modrzyńska, Protokół dyplomatyczny, etykieta i zasady savoir-vivre’u, Warszawa 2016, s. 16; J. Sutor, Etykieta dyplomatyczna z elementami protokołu i ceremoniału, Warszawa 2016, s. 25-26.

16 Zob. S.B. Linde, Słownik języka polskiego, t. 1: A-F, Lwów 1854, s. 229. 
obrzęd religijny, zwał się od tego miasta ceremonją, samo zaś miasto nazwano Sacrarium populi Romani, Diversorium sacerdotum ac Receptaculum Romanorum sacrorum ${ }^{17}$.

Niewątpliwie starożytne ceremonie ściśle powiązane były z kultem i z czynnościami sakralnymi. Musimy mieć jednak na względzie fakt, że zarówno społeczna działalność, jak i życie polityczne stanowiły z religią nierozłączną całość. Wydarzenia ze starożytnego świata politycznego przesiąknięte były odniesieniami do kultu (np. procesja z nowo wybranym senatorem, podczas której składano ofiary bogom); tak samo kult nierozerwalnie wiązał się z życiem społeczno-politycznym (np. Cyceron był jednocześnie kapłanem, prawnikiem i senatorem).

W wiekach średnich św. Tomasz z Akwinu definiować będzie łaciński termin caeremonia wyłącznie jako zewnętrzny znak czynności liturgicznej $^{18}$. Jednak już w czasach renesansu, a później szczególnie w czasach baroku, pierwotna symbioza ceremonii religijnej i ceremonii świeckiej ponownie będzie bardzo mocno widoczna: „Où tout est cérémonie”.

Podobnie, jak żyjący na przełomie XVIII i XIX wieku S.B. Linde, tak i błogosławiony A.J. Nowowiejski, pionier polskiego ruchu liturgicznego i wybitny badacz liturgii, którego największa aktywność naukowa przypadła na przełom XIX i XX wieku, w swoim monumentalnym dziele poświęconym liturgii podaje rozróżnienie na ceremonie świeckie, które dzieli na urzędowe i dworskie, oraz ceremonie religijne.

Cokolwiek bądź - czytamy u A.J. Nowowiejskiego - jeżeli w ogóle ceremoniami zowiemy formy zewnętrzne, towarzyszące pewnym uroczystym czynnościom; a w porządku urzędowym szereg formalności, używanych do podniesienia powagi władz i nadania prawom większej mocy, i na dworach królewskich i książęcych umówiony porządek zachowania się obecnych, aby powaga króla czy księcia była zachowaną, ogólny porządek utrzymany i nikt z obecnych nie obrażony, - to w liturgji ceremonje, zgodnie z nauką koncyljum Trydenckiego, są znakami zewnętrznymi,

17 A.J. Nowowiejski, Wykład Liturgii Kościoła Katolickiego, t. 1/1, Warszawa 1893, s. 12.

18 Cyt. za M. Boiteux, Ceremoniat. Zapotrzebowanie na wykwintność, w: M. Boiteux, A. Campitelli, N. Marconi, L. Simonato, G. Wiedmann, Watykan. Sztuka, architektura i ceremoniał, Kielce 2018, s. 12. 
ustanowionemi przez prawowitą władzę, dla wyrażenia kultu Bożego i pożytku duchownego ludzi ${ }^{19}$.

Zarówno ceremonie świeckie, jak i religijne, definiują pewne reguły i zwyczaje, zgodnie z którymi przebiegają. Na płaszczyźnie liturgicznej trzeba by mówić o „porządku”, zgodnie z którym sprawowane są tajemnice wiary. Natomiast na płaszczyźnie świeckiej należałoby używać słowa „protokół”. Jeden i drugi termin informuje o zwyczajach i tradycjach, o sposobie organizacji i przebiegu konkretnego wydarzenia. B.S. Linde, tłumacząc słowo „protokół”, podaje, że jest to zapis; księga, w której należy zapisać postanowienie, czyli zaprotokołować ${ }^{20}$. Współcześnie do tego rozumienia dodać musimy znaczenie protokołu jako zestaw reguł umożliwiających porozumienie, pozwalający na uniknięciu konfliktów i nieporozumień.

Podejmując analizę historyczną liturgii, dostrzegamy, że już od samego początku chrześcijaństwa obowiązywał pewien porządek celebracji, schemat, zgodnie z którym przebiegało spotkanie pierwszych chrześcijan. Świadczą o tym choćby przekazy biblijne o ustanowieniu Eucharystii przez Chrystusa, stanowiące świadectwo sprawowanej już od kilkunastu czy kilkudziesięciu lat liturgii eucharystycznej, jak i późniejsze relacje patrystyczne, jak choćby ta zawarta w Apologii św. Justyna, będąca dokumentacją ściśle ustalonego przebiegu Mszy świętej z połowy II wieku po Chrystusie $^{21}$.

Wypada dodać, że z czasem, ów ustalony i przekazywany (kolejnym pokoleniom, a także i innym Kościołom) liturgiczny porządek (ordo) znalazł odzwierciedlenie w liturgicznych ordines rozumianych jako pewien typ czy też rodzaj księgi liturgicznej. Tak więc „ordo” to zarówno „porządek”, „schemat”, „przebieg” liturgii, jak i księga, w której ów porządek spisano. W tym drugim zatem znaczeniu ordo (bądź ordinarium) to księga zawierająca liturgiczno-prawne dyspozycje odnoszące się do celebracji; innymi słowy, to rubryki niezbędne w sprawowaniu Eucharystii; konieczne tak, jak modlitwy (zawarte w sakramentarzach), czytania biblijne (zawarte w lekcjonarzach i ewangeliarzach) oraz antyfony (zawarte w an-

19 A. J. Nowowiejski, Wykład, s. 13.

20 Zob. S. B. Linde, Słownik Języka Polskiego, t. 4: P, Lwów 1858, s. 486.

21 Zob. D. Brzeziński, Mszał jako księga liturgiczna: geneza i ewolucja, „Teologia i Człowiek" 44 (2018) 4, s. 60-62. 
tyfonarzach). Najstarsze zachowane i odnalezione ordines romani sięgają VII stulecia. Za pewien rodzaj ordo rzymskiego może być uznany również tzw. liber diurnus z wieków VII i VIII, w którym podawano ryty i modlitwy związane z konsekracją papieża, czy też biskupów Kościołów podrzymskich. Ordines, będące przykładem tzw. ksiąg czystych, razem z sakramentarzami, lekcjonarzami, ewangeliarzami i antyfonarzami, weszły w skład tzw. ksiąg pełnych bądź mieszanych, powstających w Kościele na przełomie pierwszego i drugiego tysiąclecia chrześcijaństwa ${ }^{22}$.

W XVI wieku tworzone na papieskim dworze ordines dały początek dziś powszechnie znanym ceremoniałom. Uzupełniane natomiast były przez diariusze, tj. pamiętniki papieskich ceremoniarzy (m.in. A. Piccolominiego, J. Burchardta i P. Grassiego), będących nie tylko mistrzami papieskich ceremonii liturgicznych, ale również pełniących funkcję (używając współczesnego języka) szefów protokołu dyplomatycznego Państwa Kościelnego.

Słowo "porządek” (łac. ordo) czy w liczbie mnogiej "porządki” (łac. ordines) towarzyszy Kościołowi po dzień dzisiejszy. Zawierają je w swoich tytułach łacińskie wydania ksiąg liturgicznych, jak np. Ordo Baptismi Parvulorum, Ordo Initiationis Christianae Adultorum czy Ordo Confirmationis. O konieczności ponownego opracowania ordo Missae zadecydowano w Konstytucji o Liturgii Sacrosanctum Concilium II Soboru Watykańskiego ${ }^{23}$.

Odpowiednikiem porządku liturgicznego jest protokół dyplomatyczny. Encyklopedia prawa międzynarodowego i stosunków międzynarodowych zestawia go z ceremoniałem dyplomatycznym i wskazuje na zamienne użycie tych terminów:

Ceremoniał dyplomatyczny, zwany też protokołem dyplomatycznym, [to] zbiór norm regulujących formy kontaktu między obcymi przedstawicielami dyplomatycznymi a miejscowymi czynnikami urzędowymi, zwłaszcza głową państwa i ministrem spraw zagranicznych. Normy takie układa każde państwo w zasadzie według swojego uznania, wykształci-

22 Por. tamże, s. 70-73.

23 Por. R. Kaczynski (red.), Enchiridion documentorum instaurationes liturgicae, t. 1: 1963-1973, Torino 1976, s. 13. 
ły się jednak pewne standardy, których nieprzestrzeganie groziłoby państwu retorsjami ${ }^{24}$.

Wydarzenia o charakterze dyplomatycznym i liturgicznym cechują liczne znaki i symbole oraz gesty i postawy. Ich ustalenie oraz spisanie stało się na przestrzeni wieków koniecznością. Jak już wspomnieliśmy w odniesieniu do liturgii, analogicznie rzecz się ma na płaszczyźnie relacji międzynarodowych. Początkowo były to pewnego rodzaju instrukcje, porządki, notatki, które z biegiem czasu przybrały formę ksiąg, zwanych do dziś „ceremoniałami”. Nota bene, ceremoniał to także księga liturgiczna w Kościele łacińskim dotycząca celebracji biskupich (Caeremoniale Episcoporum); ceremoniał to „ordo”, a więc rubryki odnoszące się do ceremonii sprawowanych przez biskupa (bądź z jego udziałem).

Doskonałym przykładem zachowania kodyfikowanego na przestrzeni wieków ceremoniału, zarówno liturgicznego, jak i świeckiego (dyplomatycznego) oraz swoistej symbiozy między nimi zachodzącej jest oczywiście Stolica Apostolska. Dobrze tę rzeczywistość oddaje krótki opis zamieszczony przez holenderską pisarkę R. Steenbeek w książce W Rzymie jak w domu:

Czułam się jak na dworze rzymskiego cesarza. Gwardia Szwajcarska, $\mathrm{w}$ hełmach z czerwonymi pióropuszami jak u żołnierzy armii rzymskiej, wpuszczała wszystkich bogatych i ważnych tego świata oraz mnie, zwykłego śmiertelnika. Kardynałowie, biskupi, mężczyźni we frakach i mundurach obwieszeni medalami i wstęgami, kobiety w eleganckich toaletach i mantylkach na głowie. De gentiluomini del Papa, przedstawiciele arystokratycznych rodów rzymskich ze złotymi łańcuchami na piersiach, wskazywali miejsca w bazylice lśniącej od marmuru, złota i kamieni szlachetnych, czasami kiwali na przyjaciół, znajomi dostawali lepsze miejsca. Wszyscy znali wszystkich ${ }^{25}$.

Podejmując tę myśl w książce Ambasador u trzech papieży, H. Suchocka wyjaśnia relacje zachodzące między liturgią i dyplomacją, uka-

${ }^{24}$ A. Klafkowski (red.), Encyklopedia prawa międzynarodowego i stosunków międzynarodowych, Warszawa 1976, s. 46.

25 R. Steenbeek, W Rzymie jak $w$ domu, Warszawa 2014, s. 280. 
zując zarówno źródło papieskiego ceremoniału, jak i specyfikę jego formowania.

Ceremoniał Stolicy Apostolskiej - stwierdza H. Suchocka - kształtował się przez stulecia, a jego korzenie sięgały dworu cesarzy rzymskich. Ubogi rybak z Galilei, jakim był Piotr, czy nawet obywatel rzymski Paweł tego ceremoniału nie wprowadzili. Powstawał on stopniowo i do czegoś musiał się odwoływać, a to było najprostsze skojarzenie - z dworem cesarskim, wzorcem oddziałującym zarówno przez przekaz literacki, jak i malarstwo oraz architekturę. I na owe ramy ceremoniału cesarskiego nanoszone były specyficzne elementy związane z rytem katolickim ${ }^{26}$.

Ceremoniał, a więc zapis porządku/protokołu, charakteryzuje się drobiazgowym zaplanowaniem wydarzeń, uroczystości; przewidywaniem różnych możliwości, dopracowaniem każdego szczegółu z uwzględnieniem wszelkich uwarunkowań, punktów wspólnych oraz różnic.

$\mathrm{Na}$ przestrzeni lat kształtowały się porządki, zasady protokolarne, ceremoniały, u źródeł których dostrzegamy naturalną "grzeczność", a także zasady, które „od zawsze” stanowiły pewną oczywistość. Z biegiem czasu urosły one do bardziej wyrazistych i mocniejszych form, jednakże u ich źródła pozostała płynąca z ludzkiej natury moralność i obyczajność, czyli etyka.

\section{GRZECZNOŚĆ KSZTAŁTOWANA PRZEZ WIEK127}

Już blisko sto lat temu, J. Makowski, opracowując zagadnienie ceremoniału dyplomatycznego, zauważał, że ogromne niegdyś znaczenie protokołu (porządku) coraz bardziej odchodzi w zapomnienie. Niestety. Interesujące jest użycie przez J. Makowskiego kolejnego terminu - „etykieta” - słusznie kierującego nasze myśli ku etyce. Jego użycie jest uzasadnione zarówno na płaszczyźnie dyplomatycznej, a więc w odniesieniu do

26 H. Suchocka, Ambasador u trzech papieży, Kraków 2018, s. 78.

27 Nawiązanie do słów C. K. Norwida: „Są ludzie, którzy nie wiedzą o tym, że grzeczność kosztowała ludzkość wieki pracy”. 
protokołu, jak i płaszczyźnie liturgicznej, między innymi w odniesieniu do „grzeczności” okazywanej wobec konkretnych uczestników liturgii.

Ceremoniał dyplomatyczny i dworski jest wykładnikiem prawa zasadniczego państw do szacunku. Dawniej miał on wielkie znaczenie, obecnie te "graves riens", jak je dowcipnie określano, straciły cokolwiek na znaczeniu i można stwierdzić w czasach najnowszych dążenie do uproszczenia, niejako zdemokratyzowania, etykiety dyplomatycznej. W każdym razie przepisy zasadnicze tzw. Protokołu dyplomatycznego utrzymały się dotąd w mocy z pewnymi zmianami w każdej poszczególnej stolicy. [...] Obowiązuje również pewien ceremoniał w tytulaturze i formułach grzecznościowych pism dyplomatycznych. ${ }^{28}$

Francuskie słowo „étiquette”, od którego wywodzimy słowo „etykieta”, oznacza przede wszystkim „naklejkę”, „nalepkę (etykietkę)”, „oznacznik” (zestawiając je ze słowem „marque”, czyli „marka”, „brand”), następnie dopiero „etykietę" (np. dworską). Jako wyrazy synonimiczne z drugim tłumaczeniem wskazuje się: „cérémonial” (ceremoniał), „protocole” (protokół) oraz „regle” (przepis, zasada, reguła) ${ }^{29}$. Wspominany już B.S. Linde tłumaczy etykietę jako obowiązujące ceremoniały i zwyczaje. Stąd, mając na myśli wydarzenie odbywające się zgodnie z etykietą, możemy mówić: zgodnie ze zwyczajem czy ceremoniałem. Dodajmy, że w definicji słownikowej Linde wspomina o znaczeniu etykiety jako „cedułki z napisem” (dosł. zapisanej kartki).

Z kolei T. Orłowski, mówiąc o etykiecie dookreśla ją: „etykieta, czyli zasady dobrego wychowania na co dzień” lub „czyli dobre maniery”. Natomiast jako punkt wyjścia dla etyki wskazuje przestrzeganie zasad etycznych. Ponadto, w kontekście etykiety wymienia następujące zasady: wzajemności, uszanowania prywatności, starszeństwa, tolerancji, dyskrecji, punktualności oraz zdrowego rozsądku. Trudno nie odnieść wrażenia, że powyższe zasady wypełniają ustalone porządki i protokoły, i są widoczne $\mathrm{w}$ spisanych ceremoniałach i organizowanych ceremoniach.

28 J. Makowski, Prawo międzynarodowe, cz. 1: Sprawy obce, Warszawa 1930, s. $246-247$.

29 Zob. J. Dobrzyński, I. Kaczuba, B. Forsztęga (red.), Wielki słownik francusko-polski, t. 1, Warszawa 2005, s. 626. 
Niezwykle ciekawa jest owa gra słów, która wskazuje na językowe pokrewieństwo, a więc i zbliżone znaczenie słów „etykieta” i „etyka”. „Etyka”, wywodząca się od gr. „ếthos”, oznacza obyczaj. Jak zauważa M. Zdrenka, w języku polskim dość długo używany był właśnie termin „obyczajność" lub jemu synonimiczny termin „moralność” 30 .

Rzeczywiście, używając słowa „etykieta”, mamy na myśli pewną obyczajność, moralność, a więc grzeczność; grzeczność, która towarzyszy nam i obowiązuje w każdej dziedzinie i w każdej rzeczywistości. Omawiając protokół dyplomatyczny, zauważamy, że etykieta jest z nim nierozerwalna, stanowi nieodłączną jego część. Przechodząc natomiast od rzeczywistości świeckiej do tej związanej z kultem, łączenie tej drugiej z etykietą nie jest już takie oczywiste. Jednak nie sposób nie zauważyć znaczącej roli obyczaju oraz specyficznej dla wspólnoty Kościoła obyczajności, czyli właśnie etykiety. Obyczaj, wyrażany w pieśniach (np. w słowach „starych ojców obyczajem”) czy wspominany w życzeniach (,jak obyczaj każe stary, według ojców naszej wiary") nadaje swoisty rytm życiu Kościoła. Ponadto, wspomniana już naturalna „grzeczność” znajduje swoje szczególne miejsce w sprawowanej liturgii. Odnosi się ona zarówno do rzeczywistości transcendentnej, jak i sprawujących kult oraz wszystkich uczestników. Okazywana jest zarówno poprzez gesty (np. skłony, przyklęknięcia, okadzenia), jak i słowa (np. sposób zwracania się do uczestników liturgicznego zgromadzenia „bracia i siostry”). Wyrażana jest poprzez odpowiednie ukształtowanie i wyposażenie auli liturgicznej (odzwierciedlającej hierarchiczny ustrój Kościoła, a przez to również i zgromadzenia liturgicznego), śpiew i muzykę (np. introit Tu es Petrus wykonywany na wejście papieża), czy odpowiednio dobrane stroje (zarówno liturgiczne, jak i tzw. chórowe).

Naturalna grzeczność, będąca źródłem zasad i obyczajów - etykiety - przyjmowała $\mathrm{z}$ biegiem lat nowe, rozbudowane formy. Szczegółowo zaplanowana i ustalona, stała się instrumentem „propagandy” na dworach władców. Przykładem tego może być dwór papieski ${ }^{31}$ czy francuski Wersal. D. Galateria w opracowaniu dotyczącym francuskiej etykiety opi-

${ }^{30}$ Zob. M. Zdrenka, Problem uniwersalizacji etosu mieszczańskiego, Toruń 2003, s. 33-35.

31 Zob. M. Mikołajczak, Książe Apostołów - Sługa Sług Bożych. O oczyszczaniu papieskiej liturgii zświeckiego protokołu, „Teologia i Człowiek” 52 (2020) 4, s. 133-152. 
suje szczegółowo zasady panujące na Dworze Króla Słońce oraz podkreśla główną funkcję panującej tam etykiety:

By odnowiona etykieta spełniała swą propagandową funkcję, król musiał się wystawić na widok publiczny (se montrer pour contenter, dosł. „pokazywać się, by zadowolić”) i roztaczać wokół siebie aurę (zachowywać „dystans"), a także pamiętać o gestach i ścisłych porach budzenia się, posiłków, mszy i rozrywek ${ }^{32}$.

Zmiany zachodzące w świecie wymusiły zredukowanie nabrzmiałej i rozbudowanej etykiety, ogołociły monarsze dwory z towarzyszącego im splendoru, tajemnicy i „oderwania od rzeczywistości”. Jednakże podstawowe zasady, płynące z natury człowieka pozostały niezmienne. Wciąż one obowiązują i cały czas regulują relacje międzyludzkie, zarówno w codzienności, jak i podczas wydarzeń dyplomatycznych czy liturgicznych.

\section{ZAKOŃCZENIE}

Protokół dyplomatyczny, rozumiany jako pewnego rodzaju ład, zbiór zasad i zwyczajów, obowiązujący podczas spotkań, ma swój odpowiednik w liturgii, która także posiada ordo celebrationis. Choć nie ma zwyczaju mówienia o protokole liturgicznym, byłoby to - nie tylko per analogiam zasadne, biorąc pod uwagę definicję protokołu dyplomatycznego.

Ukształtowany na podstawie porządków/protokołu ceremoniał obowiązuje zarówno w rzeczywistości liturgicznej, jak i dyplomatycznej. Termin ten w sposób oczywisty odnosi się do wydarzeń „niecodziennych", a jego znaczenie zależne jest od doprecyzowania rozumienia tego terminu: ceremoniał liturgiczny, ceremoniał dworski, ceremoniał papieski czy ceremoniał królewski.

Źródłem zasad protokolarnych i ceremoniałów, mającym swoje szczególne miejsce zarówno w wydarzeniach liturgicznych, jak i dyplomatycznych, jest grzeczność, czyli etykieta. Kształtowana przez wieki, przybierała różne formy i realizowała różne zadania i cele. Jednakże zawsze stanowiła, i wciąż stanowi, fundament międzyludzkich relacji wyra-

32 D. Galateria, Wersal. Etykieta na Dworze Króla Słońce, Kraków, 2017, s. 27. 
żanych zarówno w codzienności, jak i wydarzeniach o charakterze dyplomatycznym czy liturgicznym.

Mamy nadzieję, że nasze opracowanie będzie stanowić punkt wyjścia dla dalszych badań nad relacjami zachodzącymi między liturgią i dyplomacją, rzeczywistościami niegdyś nierozłącznymi, a dziś - jak się zwykło powszechnie przyjmować - niezależnymi. Nic bardziej mylnego.

\section{BIBLIOGRAFIA}

Boiteux M., Ceremoniał. Zapotrzebowanie na wykwintność, w: M. Boiteux, A. Campitelli, N. Marconi, L. Simonato, G. Wiedmann, Watykan. Sztuka, architektura i ceremoniat, Kielce 2018, s. 11-27.

Brzeziński D., „Chrystus wczoraj i dziś, i na wieki”. Anamnetyczny wymiar roku liturgicznego, Toruń 2015.

Brzeziński D., Human Dimension of the Christian Liturgy, „Teologia i Człowiek” 48 (2019) 4, s. 71-89. DOI: https://doi.org/10.12775/TiCz.2019.043.

Brzeziński D., Mszał jako księga liturgiczna: geneza i ewolucja, „Teologia i Człowiek” 44 (2018) 4, s. 57-77. DOI: https://doi.org/10.12775/TiCz.2018.039.

Brzeziński D., W poszukiwaniu teologicznego sensu liturgii. Refleksje na 2000-lecie chrześcijaństwa, „Studia Płockie” 28 (2000), s. 37-48.

Dictionary of Medieval Latin from British Sources, http://www.dmlbs.ox.ac.uk/web/dmlbs. html (data dostępu: 8.12.2021).

Dobrzyński J., Kaczuba I., Forsztęga B. (red.), Wielki stownik francusko-polski, t. 1, Warszawa 2005.

Galateria D., Wersal. Etykieta na Dworze Króla Stońce, Kraków, 2017.

Genet R., Traité de Diplomatie et de Droit Diplomatique, Paris 1931.

Janicki J., Kultury antyczne w liturgii chrześcijańskiej, Kraków 2007.

Kaczynski R. (red.), Enchiridion documentorum instaurationes liturgicae, t. 1: 1963-1973, Torino 1976.

Klafkowski A. (red.), Encyklopedia prawa międzynarodowego i stosunków międzynarodowych, Warszawa 1976.

Linde S. B., Słownik języka polskiego, 6 t., Lwów 1854-1858.

Makowski J., Prawo międzynarodowe, cz. 1: Sprawy obce, Warszawa 1930.

Marsili S., La liturgia, momento storico della salvezza, w: S. Marsili (red.), Anàmnesis, t. 1: La liturgia, momento nella storia dela salvezza, Casale Monferrato 1979, s. 31-156.

Marsili S., Liturgia, w: D. Sartorte, A.M. Triacca (red.), Nuovo Dizionario di Liturgia, Cinisello Balsamo 1990, s. 725-742.

Mikołajczak M., Ksiąze Apostołów - Stuga Stug Bożych. O oczyszczaniu papieskiej liturgii zświeckiego protokołu, „Teologia i Człowiek” 52 (2020) 4, s. 133-152. DOI: https:// doi.org/10.12775/TiCz.2020.055.

Modrzyńska J., Protokół dyplomatyczny, etykieta i zasady savoir-vivre’u, Warszawa 2016. 
Nadolski B., Liturgika, t. 1: Liturgika fundamentalna, Poznań 1989.

Nahlik S., Narodziny nowożytnej dyplomacji, Wrocław 1971

Nowowiejski A. J., Wykład liturgii Kościoła katolickiego, t. 1/1, Warszawa 1893.

Orłowski T., Protokół dyplomatyczny. Między tradycją a nowoczesnością, Warszawa 2015.

Słownik Liddell-Scott-Jones, http://www.dictionaryportal.eu/pl/53/ (data dostępu: 8.12.2021).

Steenbeek R., W Rzymie jak w domu, Warszawa 2014

Suchocka H., Ambasador u trzech papieży, Kraków 2018.

Sutor J., Etykieta dyplomatyczna z elementami protokołu i ceremoniału, Warszawa 2016.

Sutor J., Prawo dyplomatyczne i konsularne, Warszawa 2021.

Wicquefort de A., Memoires touchant les ambassadeurs, et les ministres publics, La Haye 1677.

Zdrenka M., Problem uniwersalizacji etosu mieszczańskiego, Toruń 2003. 
